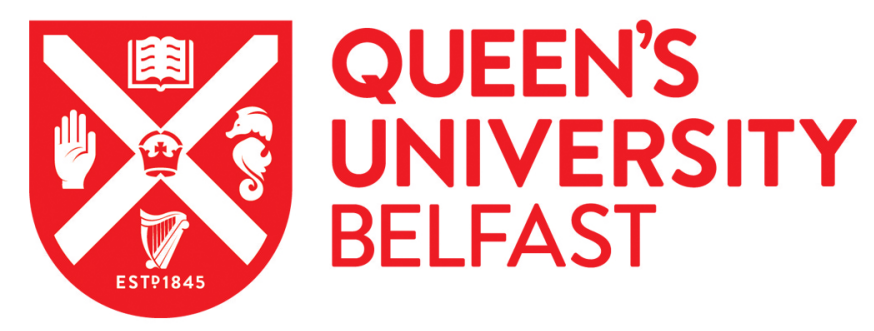

\title{
The construction of 'coast' in national planning policy
}

Crawford, J. (2019). The construction of 'coast' in national planning policy. Town Planning Review, 90(3), 299320. https://doi.org/10.3828/tpr.2019.20

\section{Published in:}

Town Planning Review

\section{Document Version:}

Peer reviewed version

\section{Queen's University Belfast - Research Portal:}

Link to publication record in Queen's University Belfast Research Portal

\section{Publisher rights}

Copyright 2019 Liverpool University Press. This work is made available online in accordance with the publisher's policies. Please refer to any applicable terms of use of the publisher.

\section{General rights}

Copyright for the publications made accessible via the Queen's University Belfast Research Portal is retained by the author(s) and / or other copyright owners and it is a condition of accessing these publications that users recognise and abide by the legal requirements associated with these rights.

Take down policy

The Research Portal is Queen's institutional repository that provides access to Queen's research output. Every effort has been made to ensure that content in the Research Portal does not infringe any person's rights, or applicable UK laws. If you discover content in the Research Portal that you believe breaches copyright or violates any law, please contact openaccess@qub.ac.uk. 
Accepted version

Title:

The Construction of 'Coast' in National Planning Policy

Author: Jenny Crawford

\section{Contents}

Abstract 2

Introduction 3

Protecting the 'undeveloped' coast 4

$\begin{array}{ll}\text { Recognising coastal heritage } & 6\end{array}$

$\begin{array}{ll}\text { ICZM in planning policy } & 6\end{array}$

$\begin{array}{ll}\text { The coast and marine spatial planning } & 10\end{array}$

$\begin{array}{ll}\text { Coast in current national planning policy frameworks } & 13\end{array}$

$\begin{array}{ll}\text { Conclusions } & 15\end{array}$

$\begin{array}{lr}\text { Acknowledgements } & 16\end{array}$

$\begin{array}{ll}\text { References } & 17\end{array}$ 
Accepted version

\begin{abstract}
'The coast' is often presented as a discrete functional object of both development and environmental policy. An alternative understanding of 'coast' as a contested spatial construct in policy processes underpins this analysis of the identities of 'coast' in English and Scottish national planning policy since the mid twentieth century. These identities are discussed in relation to fundamental tensions between conflicting conceptions of development and environmental protection within national planning policy in each jurisdiction. The paper argues that current coastal constructions potentially undermine attempts to proactively plan for the integration and innovation required to meet multiple needs across the land/sea interface.
\end{abstract}


Accepted version

\section{Introduction}

The social construction of space or place is a key component of spatial planning processes. Planning research has tended to focus on mapping and comparing what Lefebvre (1991) identified as the 'conceived' spaces created and negotiated by policymakers (Murdoch, 2006; Davoudi and Strange, 2009; Jay, 2012; Davoudi et al, 2018). At the same time, as highlighted by Healey (2007), spatial constructs or imaginaries incorporate complex layers of assumption about what is happening, what is viable, what is important and what can essentially be ignored in the human/non-human environment in responses to inherent conflicts in development interests (Pierce and Martin, 2015). This paper shifts the focus of analysis of space in policy-making to include these underlying assumptions. In particular, it aims to uncover the mobilization of multiple constructions of 'the coast' in national planning policy and to examine the implications for policy outcomes.

The construction of coastal space in spatial policy is of analytical interest for a number of reasons. Firstly, definitions of coastal boundaries are ambiguous and contested in the UK experience of coastal management and planning (Taussik, 1996; Leyshon, 2018). At the same time, the experience of coast as a contested space has strong resonances in international contexts (Davidson and Entrikin, 2005; Ryks, 2014; Sas et al, 2010; Silver, 2014; Stocker and Kennedy, 2009). Secondly, the introduction of new institutions of marine planning and management in the UK in the last decade has reframed spatial policy-making for both land and sea. The Marine Policy Statement (HM Government, 2011a) commits the UK government administrations to ensuring that coastal areas, and the activities taking place within them, are managed on the basis of 'a holistic view of the built environment, communities and environmental matters across the land/sea boundary' (DEFRA, 2011, p.12). Many commentators have emphasized that this will require integration of marine and coastal management with land use planning processes (Smith et al, 2011; Kidd and Shaw, 2014). These pressures offer an unprecedented opportunity for the observation of change in the construction of space within spatial policy processes.

The reorientation of resource governance and spatial planning, in the devolved jurisdictions of the UK, requires not only redefinition of institutional boundaries and interactions, but also changing conceptions of the relationship between land and water (both marine and freshwater) and recognition of the complexity of ecosystem dynamics and pressures (European Environmental Agency, 2006; Hull, 2013; Kidd et al, 2011; Leyshon, 2018). 
Accepted version

Indeed, as Steinberg (2013) points out, consideration of the identities ascribed to 'coast' offers the opportunity to rethink the dominant land-sea binary that reduces it to an abstract space, especially when the spatial planning systems for land and sea are institutionally separate. The construction of boundaries, territories and associations related to the interface of the terrestrial and marine thus offers a rich analytical field for spatial planning research (Jay et al, 2012; Walsh, 2018).

In order to analyse the different responses of English and Scottish planning policy to perceptions of development pressures related to the 'coast', this paper traces the changing representations and narrations, or spatial constructions of the coast in national planning policy texts for both these jursidictions since the mid twentieth century (Figure 1). It analyses the relationship of these spatial constructs to conflicting development discourses and, in particular, evaluates the implications of these relationships for processes of integration and innovation (Campbell, 2012; Hillier, 2010; Olesen, 2014, Lennon and Scott, 2014). It distinguishes four emergent themes in the development of the construction of coastal identity in national planning policy for the UK, over this period, with significant differences, as well as overlaps, between England and Scotland. These include an early emphasis on the protection of 'undeveloped' coast in the context of an urban/rural divergence in planning; the emergence of notions of 'coastal heritage'; the uneven promotion of concepts of Integrated Coastal Zone Management (ICZM) and the response to marine spatial planning. Against this historical background, the paper then discusses constructs of coast in current national planning policy frameworks and their relationship to the challenges of ecological and institutional integration across the land/sea boundary. It argues that representations of coast in national planning policy continue to reflect the latter's lack of effective engagement with these issues.

\section{Protecting the 'undeveloped' coast}

The framework of environmental protection incorporated into the British planning system in the 1930s and 1940s reflected ongoing public demands and controversies over the conservation of nature (MacEwen \& MacEwen, 1982; Cullingworth, 1988). Among the most prominently debated issues were the public goods of recreation and access to the renewing properties (physical, spiritual and moral) of nature, encapsulated in conceptions of 'beauty' (Sheail, 1975; Murdoch, 2006; Selman and Swanyck, 2010). 


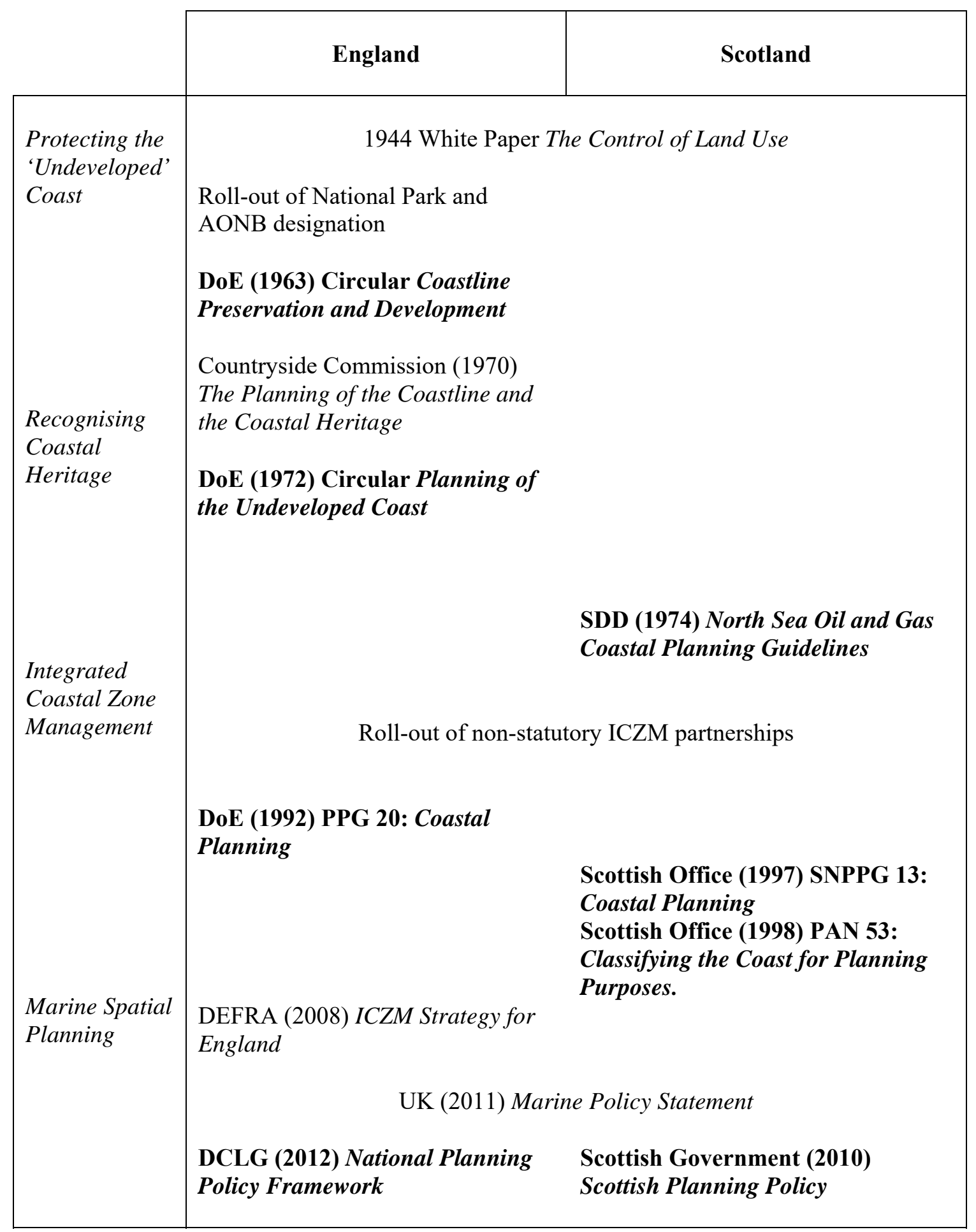

Figure 1 National planning policy for the English and Scottish coasts, 1944-2012

The 1944 White Paper, The Control of Land Use (HM Government, 1944) reified public enjoyment of both the seaside and countryside as an important aspect of post-war reconstruction, in which the establishment of national parks and the protection of areas of outstanding natural beauty were to play a central role. The drafting and implementation of the 


\section{Accepted version}

National Parks and Access to the Countryside Act 1949 struggled to overcome deep tensions between interests in the promotion of recreation and tourism development, on the one hand, and those of landscape preservation and wildlife protection, on the other (National Parks Committee, 1947). A core assumption in this conservation framework was that agricultural use was inherently compatible with environmental objectives, while other forms of land use were inherently conflictual (Curry, 1994). By the end of the 1950s, seven of England's ten national parks had been designated, while confirmed Areas of Outstanding Natural Beauty (AONB) included the North Devon Coast and Northumberland Coast AONBs.

The development of coastal policy in relation to land use planning in Scotland followed a very different trajectory from that of England (Figure 1). According to Sheail (1975), the Scottish Home Department criticised the Dower report on national parks (Dower, 1945) for adopting a conservative approach to the countryside. It noted that Dower deplored the impact of dams, pylons and pipelines on rural areas, and could therefore be expected to condemn such ventures as the new hydro-electric power schemes in the Highlands. In response to these concerns and a conviction that the issues for amenity were both less urgent and more complicated in Scotland than elsewhere in the British Isles, Scotland was excluded from the 1949 Act, and neither national parks nor a Scottish equivalent of the National Parks Commission were established.

However, the pressures for development on the Scottish coast in the late 1960s and early $70 \mathrm{~s}$ were to prove unprecedented in the face of the rapid expansion of oil and gas exploration and drilling in the North Sea. As documented by Lyddon (1983), some 70 applications for major oil-related developments were notified to the Secretary of State for Scotland between 1970 and 1975. The Scottish Development Department published the North Sea Oil and Gas Coastal Planning Guidelines in 1974. These were based on a coastal resource evaluation that distinguished, at a national scale, between 'Preferred Conservation Zones' and 'Preferred Development Zones', arguably demonstrating a key step towards a more strategic, integrated approach to coastal issues in British planning through its recognition of specific development activities.

\section{Recognising coastal heritage}

At the same time, in England, assumptions that the development and environmental protection issues arising in the land/sea interface could most appropriately be met through policies to protect 'undeveloped coast' continued to be challenged. Thus, while the process of AONB 


\section{Accepted version}

designation was to roll out through the 1960s and 1970s, a Department of the Environment Circular published in 1963 argued that further measures were needed to address the sensitivity and pressures for development in coastal areas (Cullingworth, 1988). The Ministry of Housing and Local Government was to subsequently initiate a large-scale study of planning of the coast by the National Parks Commission, leading to three survey reports (Countryside Commission, 1968, 1969, 1970a) and two sets of policy recommendations The Planning of the Coastline and The Coastal Heritage (Countryside Commission 1970b and 1970c). Among their recommendations to help 'curb current public feeling that too little preliminary thought is given by the Government to major planning proposals affecting the coast' (Countryside Commission 1970b, p.7) were the setting up of coastal regional parks, a review of military land holdings on the coast, planning policy for oil and gas exploitation and the identification of 'maritime industrial development areas'.

A proposed planning designation of Heritage Coasts by local authorities, in consultation with the Countryside Commission, was endorsed by the government (Countryside Commission, 1970c). Heritage Coasts sought to combine a wide range of complex uses and conservation interests, although still largely in sparsely developed or non-urban areas. Objectives included improving and maintaining the environmental health of inshore waters, while promoting sustainable forms of development to meet 'the economic and social needs of the small communities on these coasts' (DoE, 1992a, p.7) Further specific advice set out in DoE Circular 12/72 Planning of the Undeveloped Coast, however, highlighted the continued emphasis on protective designation of non-urban coasts. Not surprisingly, there remained ongoing concerns about the effectiveness of such mechanisms to respond to overall development pressures on coastal resources and the risks of erosion and flooding. In this context there was growing interest in Integrated Coastal Zone Management (ICZM).

\section{ICZM in planning policy}

The early stages of the development of ICZM in international and national environmental governance is generally ascribed to the adoption of a comprehensive Coastal Zone Management Act by the USA, in 1972 (Beatley et al, 2002, Pew Oceans Commission, 2003; USCOP, 2004). As Burroughs (2015) notes, this drew on the US regional tradition established and developed by the Tennessee Valley Regional Authority, with its emphasis on an integrated approach to economic regeneration, infrastructure planning and resource management. Sorensen catalogues the international proliferation of ICZM efforts during the 1970s and 1980s, in which the movement to professionalise a practice and discipline of ICZM 
Accepted version

was increasingly promoted through academic, international aid and government networks, characterised by 'a systems perspective and multi-sectoral approach' that served 'to distinguish ICZM from other types of environmental planning and management programs which occur in coastal areas' (Sorensen, 1993, p.50). It was in the context of this innovation in environmental policy that, in 1973, the Council of Europe Committee of Ministers expressed concern that:

'a considerable part of Europe's coasts is in a critical condition owing to the extremely serious biological degradation and aesthetic disfigurement caused by the indiscriminate siting of buildings, industry and tourist facilities in coastal areas.'(Council of Europe Committee of Ministers, 1973, p. 96)

This instigated the development of the European Coastal Charter, which further highlighted policy integration and was eventually endorsed by the European Parliament in 1982 (Ledoux et al, 2006).

In 1992, discourse promoting the coast as a special case was given traction within Agenda 21, agreed at the United Nations Conference on Environment and Development in Rio de Janeiro (UNESA, 1992, Brown et al, 2002). Chapter 17 of Agenda 21 is specifically aimed at 'coastal states', requiring them to commit to a set of shared objectives. These included the development and application of national resource and environmental accounting, to reflect changes in value resulting from use of coastal and marine areas. Core to Agenda 21 was the concept of sustainable development, as defined by the Brundtland Commission, and the requirement for 'integrated' decision-making (World Commission on Environment and Development, 1987, p.17). At the same time, Chapter 17 was designed to directly support the emerging provisions of the United Nations Convention on the Law of the Sea (UNCLOS) (UN, 1982). In this context, management of seas and coasts was envisaged as 'integrated in content and precautionary in ambit' (Cicin-Sain, 1993, p.11). The combined influence of UNCLOS and Agenda 21 further shaped the development of both European and UK policy for the coast. As Cicin-Sain (1993) argues, both the definition and the practice of integrated management, and integration in policy were stressed. 


\section{Accepted version}

In 1992, the UK House of Commons Select Committee on Coastal Zone Protection and Planning concluded that:

'The division between the planning control system at sea and on land may be regarded as forming the root of many of the problems with current coastal protection and planning policies... Harmonising the planning systems of below and above the low water mark seems to us to be the basic requisite for an integrated approach to planning in the coastal zone.' (House of Commons Environment Select Committee, 1992, p.30) However, the Government rejected the Committee's recommendations for a statutory framework for ICZM (DoE, 1992b; Fletcher et al 2014), on the basis that integration could be adequately met through existing planning legislation. Later that year it therefore published PPG 20, Coastal Planning (DoE 1992a). This was the first national development policy to promote coast as a strategic development issue in England and to provide specific guidance for development (Taussik, 1996). It delegated definition of coastal zones to local planning authorities, but set out a spatial typology comprising:

- the undeveloped coast, conserved both for its landscape value and for its nature conservation interest;

- other areas of undeveloped or partly developed coast;

- the developed coast, usually urbanised but also containing other major developments (e.g. ports, power stations, etc.); and

- the despoiled coast, damaged by dereliction caused by mining, waste tipping and former industrial uses.

In her review of implementation of the guidance, Taussik (1996, p.412) observes that 'the extent of planning control seawards acts to limit not only the area of planning control but, also, the perception of planners/planning authorities of what constitutes 'the coast', resulting in what she later describes (Taussik, 1997, p.12) as 'a land by the sea interpretation'. The guidance urged 'coastal authorities' to work closely together to resolve coastal issues within the context of 'estuary or coastal management plans' (DoE 1992a, p.23). This approach was to be developed subsequently in regional guidance, such as that for the South East, which included a section on 'Estuaries, the Coast and Marine Environment' and the guidance for the North West, which included particular reference to, and policies for the coast (North West Regional Association, 1994; Taussik, 1996).

In March 1996, the discussion paper Scotland's Coasts set out the government's intentions to update the 1974 and 1981 National Planning Guidelines (Scottish Office, 1996). It cited the 


\section{Accepted version}

need to address the range and diversity of issues on the coast, such as the rapid expansion of marine aquaculture and coastal tourism, and the interest in large-scale coastal quarrying. It also proposed to deal with coastal dereliction following demilitarization and the decline of industries such as shipbuilding and coal mining (Scottish Office, 1996). At the same time, in the context of European environmental directives (EC, 1979 and 1992), it noted the requirement to acknowledge nature conservation interests for the developed as well as the undeveloped coastline. Scottish National Planning Policy Guideline NPPG 13 Coastal Planning (Scottish Office, 1997) distinguished between the 'developed', 'undeveloped' and 'isolated' coast. Again, it was for local authorities to determine, in consultation with other bodies, such as SNH and the Scottish Environmental Protection Agency (SEPA), which of the above three forms of coast they covered, drawing on further advice in Planning Advice Note 53: Classifying the Coast for Planning Purposes (Scottish Office, 1998). The NPPG indicated that the 'developed coast' should be the focus for new developments which required a coastal location. Over $88 \%$ of Scotland's coastline was envisaged as falling within the 'undeveloped coast' category although this included smaller towns and villages, as well as the dispersed settlement characteristic of many parts of the Highlands and Islands. Proposals were only permissable where they could be expected to yield social and economic benefits sufficient to outweigh any potentially detrimental impact on the coastal environment and there were no feasible alternative sites within existing settlements or on other previously developed land. There was a presumption against development on the 'isolated coast' although such areas were seen as being limited in both number and extent. This categorization sat uneasily, however, with the rapidly expanding role of local planning authorities in planning for marine aquaculture (Peel and Lloyd, 2008), as the main pressures for large-scale development of fish farms were in sparsely settled and, often, remote areas.

While the existing planning systems in both England and Scotland broadened the range of sectoral issues considered in relation to the land/sea interface and claimed to work towards integration, this was largely based on a pragmatic approach allowing 'multi-sectoral development to progress with the least unintended setbacks' (Kay and Alder, 2005, p.80). It was within this overall planning policy context that ICZM progressed as a non-statutory activity in the UK (Ballinger, 2005; DEFRA, 2007; Stojanovic and Ballinger, 2009). In 1993, English Nature launched its Estuaries Initiative, enabling the employment of estuary management officers to set up local forums or partnerships and coordinate the production of integrated estuary management plans (Edwards et al, 1997; Roe, 2000; Stojanovic and Barker, 2008). Scottish Natural Heritage launched its Focus on Firths programme in 1994, with the 
Accepted version

objective of developing integrated management plans. A Scottish Coastal Forum was established in 1996 to act as an independent body to advise government on various aspects of coastal management and to encourage the formation of local coastal fora (Scottish Coastal Forum, 2004; Stead and McGlashan 2006).

In 2002, the European Commission published its Recommendation on the Implementation of ICZM, which provided Member States with the first formal guidance for reviewing coastal governance and delivering national ICZM frameworks (EC, 2002). Safeguarding Our Seas, published by DEFRA in 2002, stressed the interconnections between policy for the coast and both inland water catchment and open sea. DEFRA's subsequent Strategy for Promoting an Integrated Approach to the Management of Coastal Areas in England, published in 2008, endorsed the framework of partnership working that had developed since the 1990s (DEFRA, 2006a, 2006b, 2007, 2008). However, all these attempts at integration experienced notable 'administrative and institutional inertia', while ICZM remained 'a rather elusive concept' (Smith et al, 2011, pp.297 and 302).

\section{The coast and marine spatial planning}

The continued sidelining of ICZM in UK planning was to be further compounded by uncertainties surrounding the negotiation and introduction of new regulation and legislation to meet the requirements of EC maritime directives and new national marine policies (French, 2004, O'Hagan and Ballinger, 2009, Shipman and Stojanovic, 2007; Stephen and Jonathan, 2008, O'Riordan et al, 2008). The ICZM approach faced the emergence of marine planning as a powerful competing priority rather than a necessarily complementary underpinning. A formal evaluation in 2009 of the European ICZM Recommendation (EC, 2002) concluded that while it remained valid, 'the European Union policy context has significantly changed' (quoted in Fletcher 2014, p.264). The seaward shift was accentuated by the move towards marine planning as an economic instrument in Europe, underpinning the concept of 'Blue Growth' (EC, 2012a). In 2006, the EC adopted a Green Paper on A Future Maritime Policy for the EU (EC 2006). It championed the role of maritime spatial planning for 'a strong, growing, competitive and sustainable maritime economy in harmony with the marine environment' (p.36). Two years later, the Commission adopted the Roadmap for Maritime Spatial Planning (EC, 2008a). The Communication on Maritime Spatial Planning in the EU-Achievements and Future Development (EC, 2010) states a definition of marine spatial planning (MSP) as 'a process of spatial and temporal distribution of human activities in marine areas to achieve ecological, economic and social objectives' (para.1.1). While the 


\section{Accepted version}

Commission emphasised that the implementation of this process was the responsibility of Member States, it proposed to act as a facilitator for the development of a common approach (Drankier, 2012). In parallel, the Marine Strategy Framework Directive (MSFD) was agreed as 'the environmental pillar of the Integrated Maritime Policy for the European Union' (EC 2008b). As Qui and Jones (2013) stress, the MSFD and Integrated Maritime Policy (IMP) 'prescribe two different approaches to MSP in Europe' (p.186), with the MSFD promoting an ecosystem-based approach for environmental protection, while the IMP envisages MSP as being primarily an instrument for cross-sectoral management and providing predictability for future investments, with offshore wind energy being a major driver (Drankier, 2012, Mee et al, 2015). It is in this context that coastal planning considerations have become increasingly subsumed into a marine policy arena dominated by an economic growth agenda (Jay, 2010; Flannery \& O'Cinnéide, 2012a, Flannery \& O'Cinnéide, 2012b, Hull 2013).

The Marine and Coastal Access Act 2009 and the Marine (Scotland) Act 2010 were both required to implement the requirements of the European Marine Strategy Framework Directive. The results of DEFRA's 2006 consultation on the ICZM Strategy for England were fed directly into the development of proposals in the Marine and Coastal Access Bill, while the 'vision' set out in the Strategy itself continued the approach of meeting the overall aim of integrating land and marine management through 'existing structures and responsibilities' (DEFRA, 2008, p.7). Marine plans were expected to be compatible with local plans, with the main focus of integration occurring at the regional interface between the marine plan and the regional strategy. This fundamentally important strategic coordination mechanism was to be soon erased however as the coalition government elected in 2010 quickly moved to dismantle the regional development agencies and abolish regional strategies (Magowan, 2011).

Boyes and Elliot (2015) detail the challenges raised for integration by the number of institutional actors with responsibility for strategic decision-making in the marine environment. It is in this crowded institutional context that the marine planning system is expected to interact with town and country planning and other legislation, guidance and development plans, including consents for nationally significant infrastructure projects, such as the larger offshore renewable energy and port developments, dealt with under the Planning Act 2008. The Marine (Scotland) Act 2010 similarly provides for a comprehensive marine planning and licensing system for Scotland's inshore waters, administered by Marine Scotland. The first marine plans have been adopted for the East and South of England (HM Government, 2014), while others are in various stages of preparation for the South East, 


\section{Accepted version}

South West, North West and North East England marine plan areas. The first Scottish National Marine Plan was adopted in March 2015 (Scottish Government, 2015a) and eleven marine regions have been identified as the focus for new marine planning partnerships.

As the marine plan area boundaries extend up to the level of mean high water spring tides while terrestrial planning boundaries generally extend to mean low water spring tides, existing and proposed marine plan areas physically overlap with those of terrestrial plans. According to the Marine Policy Statement (MPS) (HM Government 2011a), integration of marine and terrestrial planning is to be achieved through consistency between policy documents, liaison between the responsible authorities and sharing of data. In addition, under the overall objective of promoting good governance, it specifically refers to a requirement that:

'Marine, land and water management mechanisms are responsive and work effectively together for example through integrated coastal zone management and river basin management plans' (HM Government 2011a, p.11).

This seeks to incorporate the ecosystem management approaches encapsulated in the European Habitats Directive (EC 1992), the European Water Framework Directive (EC 2000) and the European Floods Directive (EC, 2007), which have transformed the environmental context of development plan-making by setting up parallel cycles of strategic plan preparation and environmental reporting across the UK. The Water Framework Directive (WFD) defined biological, chemical and hydro-morphological quality and set targets for 'good ecological status', for both freshwater and coastal waters. The first tranche of river basin management plans were in place by 2009 , setting out programmes of measures to be undertaken by local and national government, water companies and other organisations, and were updated in 2015. These placed particular emphasis on the network of Natura 2000 sites, protected under the Habitats Directive.

The MPS highlights a comprehensive, and, of course, potentially conflicting, range of factors to be considered by marine plan authorities across the UK, including regeneration and economic development, air and water quality, noise, biodiversity, cultural heritage, flooding, erosion and dredging, marine aggregates, port and harbour development, shipping and the safeguarding of defence interests. It is in this context that marine plan authorities are required to liaise with terrestrial planning authorities to ensure, in particular, the development of infrastructure and other developments to secure sustainable economic growth and local jobs. At the same time the MPS explicitly states objectives of equality, community cohesion, 
Accepted version

wellbeing and health. The integration of marine plans with terrestrial planning and engagement with local communities is expected to encourage the development of "vibrant coastal communities, particularly in remote areas, which will include consideration of cultural heritage, seascape and local environmental quality' (HM Government 2011a, p.16). However, as Hull (2013) observes, marine spatial planning in the UK remains largely 'a high-level process discussing broad-brush issues and providing strategic guidance for the marine regions' and 'fishermen and coastal partnerships have felt bypassed by the consultation exercises' (pp.520-521). Rodwell et al (2013) also highlight the need for 'better engagement with fisheries and coastal communities' (p.254). The first marine plan for England, covering the East of England Inshore and Offshore areas, has been accused of being 'merely signposts to existing policies' (Edwards, 2014). It is still unclear how the engagement of the marine planning authorities in the broad agenda set out in the MPS will influence and respond to local plans. It is in this context that the impact of the new marine planning systems on the national land use planning policy frameworks is discussed in the next section.

\section{Coast in current national planning policy frameworks}

The replacement of PPG 20, along with most other planning policy guidance at the national level, by the National Planning Policy Framework (NPPF) (DCLG, 2012), represented the first major opportunity in England for national land use planning policy to acknowledge new marine spatial planning legislation. Paragraph 105 states:

'In coastal areas, local planning authorities should take account of the UK Marine

Policy Statement and marine plans and apply Integrated Coastal Zone Management across local authority and land/sea boundaries, ensuring integration of the terrestrial and marine planning regimes.' (p.25)

What are 'coastal areas' and 'Integrated Coastal Zone Management' in this context and how should terrestrial and marine planning be integrated? The emphasis of the NPPF is on taking 'full account of flood risk and coastal change' (paragraph 17). Coastal change, defined as physical change to the shoreline through erosion, coastal landslip, permanent inundation or coastal accretion, is represented as an inherent aspect of climate change, with a focus on the loss of land and infrastructure. In this context 'coastal processes' are characterised by their long term nature and inherent uncertainty, requiring integrated risk management across sectors (paragraph 168). Coastal change management is highlighted as a strategic priority for local plans to use evidence from non-statutory Shoreline Management Plans, which are prepared specifically to assess and manage risks of inundation and erosion (Potts, 1999; DCLG, 2010; Nicholls et al 2013). 
At the same time, the NPPF not only accords specific status to a national coastal walking route, as set out in the Marine and Coastal Access Act, but also to designated Heritage Coast. This describes the status of the latter in regulatory terms as 'areas of undeveloped coastline which are managed to conserve natural beauty and, where appropriate, to improve accessibility for visitors' (DCLG 2012, p.51) In fact the NPPF goes beyond this requirement to state that local planning authorities should

'maintain the character of the undeveloped coast, protecting and enhancing its distinctive landscapes, particularly in areas defined as Heritage Coast, and improve public access to and enjoyment of the coast.' (p.26)

The NPPF thus delimits definition of the coast to a discourse of technically driven risk management, on the one hand, and, on the other hand, accords it the status of a complex public good, comparable to that of a national park, which must, however, straddle two distinct spatial planning and management regimes. Urban, developed or 'despoiled' areas are essentially excluded from this coastal planning discourse, except in terms of shoreline management. Thus coastal heritage is located as synonymous with the undeveloped coast, while urban forms of cultural heritage are effectively silenced, as are their links with the complex assemblage of ecosystems through which land and sea articulate.

In Scotland, the consolidation of coastal policy in Scottish Planning Policy in 2010 revealed a significant shift towards the development of coastal areas as 'an important contributor to sustainable economic growth' (p.20). In this context, development plans are required to indicate priority locations for enhancement and regeneration, as well as identifying areas at risk from coastal erosion and flooding, and promoting public access to and along the coast. The coastal typology became:

- areas likely to be suitable for development,

- areas subject to significant constraints, and

- $\quad$ areas which are considered unsuitable for development such as the isolated coast.

The isolated coast is envisaged as 'distant from centres of population', lacking 'obvious signs of development' and being of 'very significant environmental, cultural and economic value' (p.21). Local authorities are expected to recognise that Integrated Coastal Zone Management (ICZM) 'may be of use in addressing the areas and issues in which regional marine plans and development plans have a common interest', while the landward limit of the coastal zone 'will vary based on the geographical effects of coastal processes and coastal-related human 


\section{Accepted version}

activity' (p.20). In this context, the Scottish Government's pilot Sustainable Marine Environment Initiative (SSMEI) has resulted in the adoption of a Shetland Islands' Marine Spatial Plan as supplementary guidance to the statutory local plan for Shetland (Shucksmith et al, 2014). The theme of coastal resources as an important basis for economic growth is further emphasised in the National Planning Framework for Scotland NPF3 (Scottish Government, 2014). This points to the significance of the emerging relationship between the NPF and the first National Marine Plan (NMP) (Scottish Government, 2015a). Further clarification on the alignment of the NMP with the NPF, with the former including provision for national developments outlined in the latter, is given in Circular 1/15 (Scottish Government, 2015b). Marine Planning Partnerships are expected to have the status of key agencies in the local development plan process and 'in most circumstances aligned marine and terrestrial planning and consenting regimes will be sufficient to ensure an integrated approach to planning and management of the coastal zone' (p.12).

\section{Conclusions}

Over the last seventy years, 'coast' has been identified as an intrinsic object of national planning policy in England. A focus on access to both countryside and coast was a central element of the demand for greater environmental amenity that shaped the post-World War 2 social contract and the transformational environmental planning legislation that accompanied it. Development conflicts were resolved in a strong urban/rural policy dichotomy, separating urban and industrial activities from rural and agricultural activities in different governance frameworks and underpinning an assumption that the development and management issues arising in the land/sea interface could most appropriately be met through policies to protect 'undeveloped coast'. Policy innovation to respond to spatial complexity was largely confined to the periphery of development policy-making (in, for example, non-statutory Heritage Coasts) or restrained within the boundaries of protected designations. In Scotland, the incorporation of 'coast' as an object of planning policy was somewhat later, in response to the unprecedented pressure of the oil and gas industry. This emphasised strategic evaluation of coastal resources, albeit dominated by the requirements of the sector.

However, in both jurisdictions, the significance and complexity of the resources associated with the interface of land and sea continued to demand more substantive policy responses. ICZM was developed in this context, drawing on international discourses of sustainability that necessarily destabilise boundaries associated with land ownership, place identity or government structures by stressing interconnectedness of both ecosystems and socio- 


\section{Accepted version}

environmental space. However it has struggled to respond to dominant economic development models, while the concept of Blue Growth is mainstreamed within marine spatial planning. National planning policy for 'the coast' continues to be dominated by sectoral silos and resistant to strategic innovation. Both land use and marine planning are largely interpreted as the allocation and management of areas for defined uses, reflecting the engineering model of planning (Jay, 2012, p.83; Davoudi and Strange, 2009). In this context, ICZM has been largely reframed as a mechanism for suturing marine and terrestrial planning systems along a narrow interface.

Constructs of coastal identity continue to operate uneasily against binary or 'bi-polar' (Peel and Lloyd, 2004, p.371) perceptions of terrestrial and marine environments. As Jay (2010) points out, these contrast human control of land with perceptions of the sea as 'natural' space. At the land-sea interface, which has so often been the location of intense human activity, 'natural' identity of the 'undeveloped coast' conflicts with development discourses. Planning policy has largely attempted to resolve these conflicts through the delineation of exclusive conservation and development zones on the coastline. ICZM was developed as an attempt to develop alternative responses. However engagement with the complexity of land-sea relationships is marginalized in current national policy frameworks. 'Coast' is largely framed in terms of defensive functions and natural and cultural goods, while the complex coastal ecosystems and maritime heritage of urban areas remain dominated by the rationales of urban growth and defensive infrastructure and separated from wider catchments, including land/sea interactions. Possibilities for rethinking urban settlement patterns, regeneration potentials, ecological management and restoration, around land-sea relationships, thus potentially remain underexplored and underdeveloped.

At the level of national planning policy in both England and Scotland, conceptions of 'the coast' are constrained by a sectoral, industrialist conception of development. This weakness is further exacerbated in England by the loss of strategic capacity triggered by the abolition of regional planning institutions, although this may be being redressed to some extent in city planning arrangements. In Scotland, there may be more immediate potential for strategic integration, albeit in the context of the emphasis of the National Planning Framework and National Marine Plan on the nationally significant economic potential of 'coastal' areas. The recognition of the co-location of complex environmental vulnerabilities with development potential could, however, still underpin innovative responses through the development and implementation of integrated plans by local or regional partnerships seeking to address 
Accepted version

land/sea relationships. Further research into how these emerging institutions construct coastal identity at strategic city and local planning policy levels can be expected to be of particular relevance for planning practice.

\section{Acknowledgements}

The author would like to thank Simin Davoudi and Paola Gazzola for their support with this research. Thanks also to Christina Kelly, Wesley Flannery and anonymous reviewers for their detailed and helpful comments on an earlier draft of the paper. The paper is based on research funded by Lord Adams Fellowship and Earl Grey Fellowship, under the auspices of Newcastle University Institute for Sustainability. All content is, however, the sole responsibility of the author. 
Accepted version

References

BALLINGER, R. (2005) 'A sea change at the coast: the contemporary context and future prospects of integrated coastal management in the UK', in: Smith, H. and Potts, J.(eds.), Managing Britain's Marine and Coastal Environment. Abingdon: Routledge and the National Maritime Museum

BEATLEY, T., BROWER, D., SCHWAB, A. (2002) An Introduction to Coastal Zone Management. Washington DC: Island Press.

BOYES, S. and ELLIOT, M. (2015) The excessive complexity of national marine governance systems - Has this decreased in England since the introduction of the Marine and Coastal Access Act 2009? Marine Policy 51: 57-65

BROWN, K., TOMPKINS, E.L. and ADGER, W.N. (2002) Making Waves: Integrating Coastal Conservation and Development, London, Earthscan.

BURROUGHS, R (2015) Feedback switching and the evolution of US coastal management. Marine Policy 53, 94-100.

CAMPBELL, H. (2012) 'Planning ethics' and rediscovering the idea of planning. Planning Theory 11(4): 379-399.

CICIN-SAIN, B. (1993) Sustainable Development and Integrated Coastal Management. Ocean and Coastal Management 21, 11-43.

COUNCIL OF EUROPE COMMITTEE OF MINISTERS (1973) On the Protection of Coastal Areas. Resolution (73) 29, https://rm.coe.int/09000016804f0990 (accessed 5 April 2014).

Countryside and Rights of Way Act 2000 c.37, http://www.legislation.gov.uk/ukpga/2000/37/contents (accessed 2 February 2015).

COUNTRYSIDE COMMISSION (1968) The Coasts of England and Wales: Measurements of Use, Protection and Development. London: HMSO. 
Accepted version

COUNTRYSIDE COMMISSION (1969) Coastal Recreation and Holidays, Special Study Report Volume 1, London, HMSO.

COUNTRYSIDE COMMISSION (1970a) Nature Conservation at the Coast, Special Study Report Volume 2, London, HMSO.

COUNTRYSIDE COMMISSION (1970b) The Planning of the Coastline, London, HMSO.

COUNTRYSIDE COMMISSION (1970c) The Coastal Heritage: A Conservation Policy for Coasts of High Quality Scenery, London, HMSO.

CUllingWORTH, J. B. (1988) Town and Country Planning in Britain, 10th edition, London, Unwin Hyman.

CURRY, N. (1994) Countryside Recreation, Access and Land Use Planning, London, Spon.

DAVIDSON, R. and ENTRIKIN, J. (2005) The Los Angeles Coast as a Public Place Geographical Review 95, (4): 578-593

DAVOUDI, S. and STRANGE, I. (eds) (2009) Conceptions of Space and Place in Strategic Spatial Planning, London, Routledge.

DAVOUDI, S., CRAWFORD, J., RAYNOR, R., REID, B., SYKES, O. and SHAW, D. (2018) Spatial imaginaries: tyrannies or transformations? Town Planning Review 2018 89, 97 124

DCLG (Department for Communities and Local Government) (2010a) Planning Policy Statement 25: Development and Flood Risk, London, DCLG.

DCLG (2010b) Planning Policy Statement 25 Supplement: Development and Coastal Change, London, DCLG.

DCLG (2012) National Planning Policy Framework, 
Accepted version

https://www.gov.uk/government/uploads/system/uploads/attachment_data/file/6077/2116950. pdf (accessed 16 February 2015).

DEFRA (Department for Environment, Food and Rural Affairs) (2002) Safeguarding Our Seas: a Strategy for the Conservation and Sustainable Development of Our Marine Environment, London, DEFRA.

DEFRA (2003) Shoreline Management Plans, http://www.defra.gov.uk/environment/flooding/policy/guidance/smp.htm (accessed 10 September 2012)

DEFRA (2004) Making Space for Water: Taking Forward a New Government Strategy for Flood and Coastal Erosion Risk Management in England - a Consultation Exercise, London, DEFRA.

DEFRA (2005) Making Space for Water: Taking Forward a New Government Strategy for Flood and Coastal Erosion Risk Management in England (First Government response to the autumn 2004 Making space for water consultation exercise), London, DEFRA.

DEFRA (2006a) Promoting an Integrated Approach to Management of the Coastal Zone (ICZM) in England: a Consultation Document, London, DEFRA.

DEFRA (2006b) Report from the United Kingdom: Implementation of (2002/413/EC) Recommendation of the European Parliament and of the Council, of 3 May 2002, concerning the implementation of Integrated Coastal Zone Management in Europe, http://www.defra.gov.uk/environment/marine/documents/protected/iczm/ukreportmarch06.pdf (accessed 5 September 2013).

DEFRA (2007) Summary of Responses to the Consultation: Promoting an Integrated Approach to Management of the Coastal Zone (ICZM) in England, London, DEFRA.

DEFRA (2008) A Strategy for Promoting an Integrated Approach to the Management of Coastal Areas in England, London, DEFRA .

DEFRA (2011) A Description of the Marine Planning System for England, London, DEFRA. 
Accepted version

DoE (Department of the Environment) (1963) Circular: Coastline Preservation and Development, London, HMSO.

DoE (1972) Circular: Planning of the Undeveloped Coast, London, HMSO.

DoE (1992a) PPG 20, Coastal Planning, London, HMSO.

DoE (1992b) Government's response to the second report from the House of Commons Select Committee on the environment: Coastal Zone Planning and Management, London, HMSO.

DoE (1992c) PPG12, Development Plans and Regional Planning Guidance, London, HMSO.

DOWER, J (1945) National Parks in England and Wales, Cmd6628, London, HMSO.

DRANKIER, P (2012) Embedding Maritime Spatial Planning in National Legal Frameworks. Journal of Environmental Policy and Planning 14, 7-27.

EC (European Commission) (1979) Council Directive 79/409/EEC on the conservation of wild birds, Brussels, European Commission.

EC (1992) Council Directive 92/43/EEC on the conservation of natural habitats and of wild fauna and flora, Brussels, European Commission.

EC (1999a) Towards a European Integrated Coastal Zone Management (ICZM) Strategy: General Principles and Policy Options, Luxembourg, Office for Official Publications of the European Communities.

EC (1999b) Lessons from the European Commission's demonstration program on integrated coastal zone management (ICZM), Brussels, European Commission.

EC (2000a) Directive 2000/60/EC of the European Parliament and of the Council establishing a framework for Community action in the field of water policy, Brussels, European Commission. 
Accepted version

EC (2000b), On Integrated Coastal Zone Management: A Strategy for Europe, COM/00/547, Luxembourg, Office for Official Publications of the European Communities.

EC (2002) Recommendation of the European Parliament and of the Council 2002/413/EC on the Implementation of Integrated Coastal Zone Management, Brussels, European Commission.

EC (2006) Green Paper - Towards a Future Maritime Policy for the Union: a European Vision for the Oceans and Seas, COM (2006) 275, Brussels, European Commission.

EC (2007) Directive 2007/60/EC of the European Parliament and of the Council of 23 October 2007 on the assessment and management of flood risks (Floods Directive), Brussels, European Commission.

EC (2008a) Roadmap for Maritime Spatial Planning: Achieving Common Principles in the EU (COM/2008/791), Communication, Brussels, European Commission.

EC (2008b) Directive 2008/56/EC of the European Parliament and of the Council of 17 June 2008 establishing a framework for community action in the field of marine environmental policy (Marine Strategy Framework Directive), Brussels, European Commission.

EC (2009) Council Directive 2009/147/EC on the conservation of wild birds, Luxembourg, Official Journal of the European Union.

EC (2010) Communication on Maritime Spatial Planning in the EU - Achievements and Future Development COM (2010) 771, Brussels, European Commission.

EC (2011) Council Directive 2011/92/EU on the assessment of the effects of certain public and private projects on the environment (Environmental Impact Assessment Directive), Luxembourg, Official Journal of the European Union.

EC (2012a) Communication from the Commission to the European Parliament, the Council, the European Economic and Social Committee and the Committee of the Regions: Blue Growth Opportunities for Marine and Maritime Sustainable Growth, COM (2012) 494, Brussels, European Commission. 
Accepted version

EC (2012b) Links between the Marine Strategy Framework Directive (MSFD 2008/56/EC) and the Nature Directives (Birds Directive 2009/147/EEC and Habitats Directive 92/43/EEC)

http://ec.europa.eu/environment/nature/natura2000/marine/docs/FAQ\%20final\%202012-0727.pdf (accessed 21 October 2012).

EDWARDS, J. (2014) Lessons to be learned from the first Marine Plan. http://www.wildlifetrusts.org/blog/joan/2014/04/02/lessons-be-learned-first-marine-plan (accessed 5 April 2014).

EDWARDS, S., JONES, P., and NOWELL, D. (1997) Participation in coastal zone management initiatives: a review and analysis on examples from the UK. Ocean and Coastal Management 36, 143-165.

EUROPEAN ENVIRONMENTAL AGENCY (2006) The Changing Faces of Europe's Coastal Areas, Luxembourg, Office for Official Publications of the European Communities.

FLANNERY, W. \& O'CINNÉIDE, M. (2012a) A roadmap for marine spatial planning: A critical examination of the European Commission's guiding principles based on their application in the Clyde MSP Pilot Project, Marine Policy, 36, 265-271.

FLANNERY, W. \& O'CINNÉIDE, M. (2012b) Deriving Lessons Relating to Marine Spatial Planning from Canada's Eastern Scotian Shelf Integrated Management Initiative, Journal of Environmental Policy \& Planning, 14, 97-117.

FLETCHER, S., JEFFERSON, R., GLEGG, G., RODWELL, L., DODDS, W. (2014) England's evolving marine and coastal governance framework, Marine Policy 45, 261-268.

Flood Risk Management (Scotland) Act 2009

http://www.legislation.gov.uk/asp/2009/6/pdfs/asp_20090006_en.pdf (accessed on 13 November 2013).

Flood and Water Management Act 2010 http://www.legislation.gov.uk/ukpga/2010/29/contents (accessed on 13 November 2013). 
Accepted version

FRENCH, P (2004) The changing nature of, and approaches to, UK coastal management at the start of the twenty-first century, The Geographical Journal 170, 116-125.

HEALEY, P. (2007) Urban Complexity and Spatial Strategies: Towards a Relational Planning for our Time; Routledge, London

HILLIER, J. (2010) 'Strategic navigation in an ocean of theoretical and practice complexity', in Hillier, J., Healey, P. eds The Ashgate Research Companion to Planning Theory. Farnham: Ashgate, pp.447-480

HM GOVERNMENT (1944) The Control of Land Use, White Paper, Cmd 6537, London, HMSO.

HM GOVERNMENT (2011a) UK Marine Policy Statement, London, TSO.

HM GOVERNMENT (2011b) The Natural Choice: securing the value of nature. London, TSO.

HM GOVERNMENT (2014) East Inshore and East Offshore Marine Plans, https://www.gov.uk/government/uploads/system/uploads/attachment_data/file/312496/eastplan.pdf (accessed on 21 July 2014).

HM GOVERNMENT (2018) South Inshore and South Offshore Marine Plans, https://assets.publishing.service.gov.uk/government/uploads/system/uploads/attachment_data/ file/726867/South_Marine_Plan_2018.pdf(accessed 15 December 2018)

HOUSE OF COMMONS ENVIRONMENT SELECT COMMITTEE (1992) Coastal Zone Protection and Planning (Second Report), London, HMSO.

HULL, A. (2013) Managing competition for marine space using the tools of planning in the UK, Planning Practice and Research, 28, 503-526.

JANßEN, H., KIDD, S. and KVINGE, T. (2013) A spatial typology for the sea: A contribution from the Baltic, Marine Policy, 42, 190-197. 
Accepted version

JAY, S. (2010) Built at sea: Marine management and the construction of marine spatial planning, Town Planning Review 81, 173-191.

JAY, S. (2012) Marine Space: Manoeuvring Towards a Relational Understanding, Journal of Environmental Policy and Planning 14, 81-96.

KAY, R. and ALDER, J. (2005) Coastal Planning and Management (2nd edition), London, Taylor and Francis.

KIDD, S., MALTBY, E., ROBINSON, L., BARKER, A., LUMB, C. (2011) 'The Ecosystem Approach and Planning and Management of the Marine Environment', in S. Kidd, A. Platerand C. Frid, (eds) The Ecosystem Approach to Marine Planning and Management, London, Earthscan, 1- 33.

KIDD, S. and SHAW, D. (2014) The social and political realities of marine spatial planning: some land-based reflections. ICES Journal of Marine Science 71, 1535-1541.

LEDOUX, L., VERMAAT, J., BOUWER, L., SALOMONS, W. and TURNER, K. (2006) 'ELOISE research and the implementation of EU policy in the coastal zone', in J. Vermaat, L. Bouwer, K. Turner, and W. Salomons (eds) Managing European Coasts: Past, Present and Future, Berlin, Springer, 1-58.

LEFEBVRE, H (1991) The Production of Space. (translated by Donald Nicholson-Smith); Oxford: Basil Blackwell.

LENNON, M. and SCOTT, M. (2014) Delivering ecosystems services via spatial planning: reviewing the possibilities and implications of a green infrastructure approach, Town Planning Review 85, 563-587.

LEYSHON, C. (2018) Finding the coast: environmental governance and the characterization of land and sea, Area, 50, 150-158. 
Accepted version

LYDDON, W. (1983) Land use and environmental planning for the development of North Sea gas and oil: The Scottish experience. Environmental Impact Assessment Review 4, 473492.

MACEWEN, A., MACEWEN, M. (1982) National Parks: conservation or cosmetics? The Resource Management Series, 5. London: Allen and Unwin.

MAGOWAN, L. (2011) Practice and Prospects for Integrated Coastal Zone Management in the UK, PhD Thesis, University of Liverpool.

Marine and Coastal Access Act 2009, http://www.legislation.gov.uk/ukpga/2009/23/pdfs/ukpga_20090023_en.pdf (accessed 10 October, 2012).

MARINE SCOTLAND (2010) Scottish Sustainable Marine Environment Initiative. Project Evaluation, Edinburgh, Marine Scotland.

MARINE SCOTLAND (2014) Scotland's National Marine Plan. Edinburgh, The Scottish Government.

Marine (Scotland) Act 2010, http://www.legislation.gov.uk/asp/2010/5/pdfs/asp_20100005_en.pdf, (accessed 30 October 2012).

MASSEY, D. (2005) For Space. London: SAGE.

MEE, L., COOPER, P., KANNEN, A., GILBERT, A. and O'HIGGINS, T. (2015) Sustaining Europe's seas as coupled social-ecological systems, Ecology and Society 20, 1.

MULRENNAN, M. and SCOTT, C. (2000) Mare Nullius: Indigenous rights in saltwater environments. Development and Change 31: 681-708

MURDOCH, J. (2006) Post-structuralist geography: a critical introduction; London, SAGE. 
Accepted version

NATIONAL PARKS COMMITTEE (1947) Report of the National Parks Committee (England and Wales), Cmd 7121, London, HMSO.

National Parks and Access to the Countryside Act 1949

http://www.legislation.gov.uk/ukpga/1949/97/pdfs/ukpga_19490097_en.pdf (accessed 12

December 2014).

NICHOLLS, R., TOWNEND, H., BRADBURY, A., RAMSBOTTOM, D., DAY, S. Planning for long-term coastal change: Experiences from England and Wales, Ocean Engineering 71, 3-16.

NORTH WEST REGIONAL ASSOCIATION (1994) Greener Growth: Regional Planning guidance for North West England, Manchester, North West Regional Association.

O'HAGAN, A. and BALLINGER, R. (2009) Coastal governance in North West Europe: An assessment of approaches to the European stocktake, Marine Policy 33, 912-922.

OLESEN, K. (2014) The neoliberalisation of strategic spatial planning. Planning Theory 13(3): 288-303.

O'RIORDAN, T., NICHOLSON-COLE, S. and MILLIGAN, J. (2008) Designing sustainable coastal futures, Twenty-First Century Society, 3, 145-157.

PEEL, D. and LLOYD, G. (2004) The social reconstruction of the marine environment: towards marine spatial planning? The Town Planning Review, 75, 359-378.

PEEL, D. and LLOYD, G. (2008) Government and planning policy in the marine environment: regulating aquaculture in Scotland. The Geographical Journal 174, 361-373

PEW OCEANS COMMISSION (2003) America's Living Oceans: Charting a Course for Sea Change, Arlington, VA, Pew Oceans Commission.

PIERCE, J., MARTIN, D., MURPHY, J (2011) Relational place-making: the networked politics of place, Transactions of the Institute of British Geographers 36: 54-70 
Accepted version

PIERCE, J. and MARTIN, D. (2015) Placing Lefebvre. Antipode 47(5):1279-1299

Planning Act, 2008, http://www.legislation.gov.uk/ukpga/2008/29/contents (accessed 17 October 2015).

POTTS, J. (1999) The non-statutory approach to coastal defence in England and Wales:

Coastal Defence Groups and Shoreline Management Plans, Marine Policy 23, 479-500.

QIU, W. and JONES, P. (2013) The emerging policy landscape for marine spatial planning in Europe. Marine Policy, 39, 182-190.

RODWELl, L., FLETCHER, S., GLEGG, S., CAMPBELl, M., REES, S., ASHLEY, M., Linley, E., FROST, M., EARLl, B., WYNNE, R., MEE, L., ALMADA-VILlELA, P., LEAR, D., STANGER, P., COLENUTT, A., DAVENPORT, F., BARKER BBRADSHAW, N. and COVEY, R. (2014) Marine and coastal policy in the UK: Challenges and opportunities in a new era. Marine Policy, 45, 251-258

ROE, M. (2000) Landscape Planning for Sustainability: Community participation in Estuary Management Plans, Landscape Research, 25, 157-181.

RYKS, J. (2014) Land/seascapes of exclusion: The new colonial project. Asia Pacific Viewpoint 55(1): 38-53.

SAS, E., FISCHHENDLER, I., PORTMAN, M. (2010) The demarcation of arbitrary boundaries for coastal zone management: The Israeli case. Journal of Environmental Management 91: 2358-2369.

SCOTTISH COASTAL FORUM (2004) A strategy for Scotland's coast and inshore waters: statement of intent, Edinburgh, Scottish Coastal Forum

SCOTTISH DEVELOPMENT DEPARTMENT (1974) North Sea Oil and Gas Coastal Planning Guidelines, Edinburgh, Scottish Office.

SCOTTISH EXECUTIVE (2005) Seas the opportunity: a strategy for the long term sustainability of Scotland's coasts and seas, Edinburgh, The Scottish Government. 
Accepted version

SCOTTISH GOVERNMENT (2010) Scottish Planning Policy, Edinburgh, The Scottish Government.

SCOTTISH GOVERNMENT (2014) National Planning Framework 3, Edinburgh, The Scottish Government.

SCOTTISH GOVERNMENT (2015a) Scotland's National Marine Plan: A Single Framework for Managing Our Seas, Edinburgh, The Scottish Government.

SCOTTISH GOVERNMENT (2015b) Circular 1/2015: The Relationship Between the Statutory Land Use Planning System and Marine Planning and Licensing, Edinburgh, The Scottish Government.

SCOTTISH OFFICE (1996) Scotland's Coasts. A Discussion Paper, Edinburgh, HMSO.

SCOTTISH OFFICE (1997) National Planning Policy Guideline 13-Coastal Planning Available at http://www.gov.scot/Publications/1997/08/nppg13-coastal Accessed on 15 May 2014

SCOTTISH OFFICE (1998) Planning Advice Note 53-Classifying the Coast for Planning Purposes, Edinburgh, HMSO.

SELMAN, P. and SWANWICK, C. (2010) On the meaning of natural beauty in landscape legislation, Landscape Research, 35, 3-26.

SHEAIL, J. (1975) The concept of national parks in Great Britain 1900-1950, Transactions of the Institute of British Geographers 66, 41-56.

SHIPMAN, B. and STOJANOVIC, T. (2007) Facts, fictions and failures of integrated coastal zone management in Europe, Coastal Management 35, 375-398.

SHUCKSMITH, R., GRAY, L., KELLY, C. and TWEDDLE, J. (2014) Regional marine spatial planning - The data collection and mapping process, Marine Policy, 50, 1-9. 
Accepted version

SILVER, J. (2014) From fishing to farming: Shellfish aquaculture expansion and the complexities of ocean space on Canada's west coast. Applied Geography 54, 110-117

SMITH, H., MAES, F., STOJANOVIC, T. and BALLINGER, R. (2011) The integration of marine and spatial planning, Journal of Coastal Conservation, 15, 291-303.

SMITH, H., BALLINGER, R. and STOJANOVIC, T. (2012) The Spatial Development Basis of Marine Spatial Planning in the United Kingdom, Journal of Environmental Policy \& Planning, 14, 29-47.

SORENSEN, J (1993) The International Proliferation of Integrated Coastal Zone Management Efforts, Ocean and Coastal Zone Management 21, 45-80.

STEAD, S. and MCGLASHAN, D. (2006) A coastal and marine national park for Scotland in partnership with Integrated Coastal Zone Management. Ocean Coastal Management 49, 2241.

STEINBERG, P. (2013) Of other seas: metaphors and materialities in maritime regions.

Atlantic Studies: Global Currents 10(2): 156-169

STEPHEN, F. and JONATHAN, P. (2008) Coastal and marine governance in the United Kingdom Editorial, Geographical Journal 174, 295-298.

STOCKER, L. and KENNEDY, D. (2009) Cultural models of the coast in Australia: toward sustainability, Coastal Management 37: 387-404

STOJANOVIC, T. and BALLINGER, R. (2009) Integrated coastal management: a comparative analysis of four UK initiatives, Applied Geography, 29, 49-62.

STOJANOVIC, T. and BARKER, N. (2008) Improving governance through local coastal partnerships in the UK, The Geographical Journal, 174, 344-360.

STOJANOVIC, T. and FARMER, C. (2013) The development of world oceans and coasts and concepts of sustainability, Marine Policy 42, 157-165. 
Accepted version

TAUSSIK, J. (1996) Development plans and the coastal zone, Town Planning Review, 67, $397-420$.

TAUSSIK, J. (1997) The influence of institutional systems on planning the coastal zone: experience from England/Wales and Sweden, Planning Practice and Research, 12, 9-19.

UN (United Nations) (1982) United Nations Convention on the Law of the Sea. New York: $\mathrm{UN}$.

UNESA (United Nations Department of Economic and Social Affairs) (1992) Agenda 21, https://sustainabledevelopment.un.org/content/documents/Agenda21.pdf (accessed on 15 February 2015).

USCOP (U.S. Commission on Ocean Policy) (2004) An Ocean Blueprint for the 21st Century: Final Report, Washington, D.C. , USCOP.

WALSH, C. (2018) Metageographies of coastal management: negotiating spaces of nature and culture at the Wadden sea, Area, 50, 177-185

WORLD COMMISSION ON ENVIRONMENT AND DEVELOMENT (1987) Our Common Future, Oxford: Oxford University Press 
Accepted version 